Hanna Cichocka

ORCID: 0000-0002-2733-3548

Uniwersytet Humanistycznospołeczny SWPS we Wrocławiu

https://doi.org/10.19195/1733-5779.37.8

\title{
Glosa do wyroku Trybunału Sprawiedliwości z dnia 7 grudnia 2017 roku w sprawie C-329/16
}

\section{JEL Classification: K33}

Słowa kluczowe: produkt medyczny, system medyczny, dane, cel medyczny, medyczny kontekst

Keywords: medical system, medical software, data, medical purpose, medical context

Abstrakt: Tekst odnosi się do problemu klasyfikacji oprogramowania medycznego jako wyrobu medycznego. Autor popiera stanowisko Trybunału Sprawiedliwości Unii Europejskiej — wyrażone w sprawie C-329/16 z dnia 7 grudnia 2017 roku — które odnosi się do tego, że oprogramowanie medyczne może stanowić w świetle prawa wyrób medyczny bez względu na to, czy bezpośrednio oddziałuje na ludzkie ciało. Co ważne, oprogramowanie to musi być czymś więcej niż systemem wyłącznie zbierającym dane pacjentów. Takie oprogramowanie medyczne wymaga specjalistycznego celu oraz umiejscowienia w określonym kontekście medycznym.

\section{Gloss to the Judgement of the Court of Justice of December 7, 2017, in case C-329/16}

Abstract: The article discusses the problem with classifying medical software as a medical system. The author supports the line of Court of Justice of the European Union — in case C-329/16 of December 7, 2017 — which states that the medical software could be a medical system, regardless of whether it affects the human body, but it would have to be more than just a data collector. The medical software must serve a medical purpose and in a medical context only.

\section{Przedmiot glosy}

Przedmiotem glosy jest wyrok Trybunału Sprawiedliwości Unii Europejskiej w sprawie Snitem i Philips France z dnia 7 grudnia 2017 r. o numerze sprawy C-329/16, w którym Trybunał orzekł co do wykładni art. 1 ust. 1 i art. 1 ust. 2 lit. a) dyrektywy Rady 93/42/EWG z dnia 14 czerwca 1993 r. dotyczącej wyrobów medycznych (Dz.U. z 1993 r., L 169, s. 1), zmienionej dyrektywą 2007/47/WE Par- 
lamentu Europejskiego i Rady z dnia 5 września 2007 r. (Dz.U. z 2007 r., L 247, s. 21), zwanej dalej dyrektywą 93/42.

Wniosek w sprawie został złożony na podstawie sporu toczącego się między Syndicat national se l'industrie des technologies medicales (Snitem) i Philips France a ministrem odpowiedzialnym za sprawy społeczne i zdrowia we Francji w sprawie obowiązku certyfikacji oprogramowania wspomagającego przypisywanie leków oraz oprogramowania wspomagającego wydawanie produktów leczniczych przewidzianych w kodeksie ubezpieczeń społecznych (JORF) z dnia 15 listopada 2014 r. (s. 19255), (dalej: dekret nr 2014-1359).

Trybunał odniósł sie do kwestii klasyfikacji oprogramowania monitorującego stan zdrowia pacjenta jako wyrób medyczny oraz poruszył kwestie traktującą o możliwości zaliczenia do wyrobów medycznych oprogramowania - w myś1 art. 1 ust. 2 lit. a) dyrektywy 93/42 — które nie oddziałuje bezpośrednio na ciało człowieka.

\section{Stan faktyczny oraz pytanie prejudycjalne}

Punktem wyjścia rozważań Trybunału Sprawiedliwości Unii Europejskiej był nastepujący stan faktyczny. Snitem zrzesza przedsiębiorstwa z branży medycznej. Do tego grona należy Philips France, specjalizujący się między innymi w zakresie opieki zdrowotnej i sprzedający oprogramowanie medyczne, umożliwiając przypisywanie pacjentom leków.

Philips France oraz Snitem wniosły do Rady Stanu Francji (Conseil d'Etat) skarge o stwierdzenie nieważności art. 1 pkt 3 traktującego o obowiązku certyfikacji każdego oprogramowania, które ma na celu pomóc osobom praktykującym w prywatnym gabinecie, a także art. 2 stanowiącego o obowiązku certyfikacji każdego oprogramowania, ujętych w dekrecie nr 2014-1359. Zdaniem strony wnioskującej do legalizacji funkcjonowania oprogramowania medycznego wystarcza uzyskanie oznakowania „CE”, poświadczającego o trosce o bezpieczeństwo oraz zdrowie ludzkie; istotne okazały się też kwestie ekonomiczne związane z dodatkowym obowiązkiem przestrzegania wymogów prawa krajowego. Naraża to stronę sporu na straty związane z przeszkodami handlowymi, co bezpośrednio i niewątpliwie przeczy art. L 161-37 kodeksu ubezpieczeń społecznych (dekret nr 2014-1359). Przepisy art. L 161-38 kodeksu ubezpieczeń społecznych, odnoszące sie do zastosowania zasady dobrych praktyk podczas procedury certyfikacji, oraz wymienionego dekretu 2014-1359 naruszają cele art. 4 wspomnianej dyrektywy (stanowiący o braku ograniczeń odnośnie do wprowadzenia do obrotu i używania wyrobów opatrzonych znakiem „CE”).

W przedmiotowym stanie faktycznym rząd francuski uznał, ze oprogramowanie mające na celu wspomaganie lekarza w doborze leków i monitorowaniu stanu zdrowia pacjenta nie może zostać uznane za wyrób medyczny. Uznano bo- 
wiem, że pełni ono funkcję jedynie pomocniczą w całym procesie podejmowania decyzji przez lekarza, ponadto nie przejawia samo w sobie oddziaływania na ciało człowieka; dysponuje narzędziami, które ułatwiają podejmowanie decyzji, dostarczając specjalistycznej wiedzy na temat stanu zdrowia pacjenta, nie jest to natomiast ingerencja w ciało, co według rządu francuskiego decyduje o nieprzyznaniu oprogramowaniu statusu wyrobu medycznego.

Strona skarżąca w postępowaniu głównym podnosi także kwestię naruszenia art. 8 dyrektywy 93/42, traktującego o konieczności wycofania danego wyrobu z obrotu, gdy stanowi zagrożenie życia i zdrowia konsumenta, ze względu na obowiązek certyfikacji przewidziany w prawie krajowym, który nie może być jednoznaczny z zastosowaniem klauzuli ochronnej w rozumieniu tego przepisu.

Ponadto strona podaje przykład naruszenia art. 34 TFUE (nt. niemożności stosowania zakazów między państwami członkowskimi UE w stosowaniu ograniczeń ilościowych w przywozie) wobec obowiązku dostosowania oprogramowania do norm technicznych, co jednoznacznie skutkuje zastosowaniem ograniczeń ilościowych w przywozie. Mając to na względzie, można stwierdzić, że obowiązek certyfikacji wyrobów medycznych wraz z art. 34 TFUE jest w przytoczonym stanie faktycznym sprzeczny z zasadą proporcjonalności i konieczności.

Wobec tak przedstawionych zastrzeżeń Rada Stanu zawiesiła postępowanie i zwróciła się do Trybunału Sprawiedliwości, formułując pytanie prejudycjalne.

Dotyczyło ono przede wszystkim interpretacji dyrektywy (93/42) w odniesieniu do oprogramowania medycznego, którego celem jest pomoc medykom pracującym w prywatnych gabinetach medycznych, zakładach opieki zdrowotnej, zakładach medyczno-społecznych, w ustaleniu zasadności wyboru przepisywanych leków, co bezpośrednio przełoży się na zwiększenie bezpieczeństwa terapii czy ułatwienie świadczenia pracy, jednak przy zachowaniu tej samej jakości usług. Punktem głównym pytania prejudycjalnego uczyniono kwestię, czy wspomniane oprogramowanie można traktować jako wyrób medyczny w rozumieniu dyrektywy (93/42), gdy zawiera ono funkcjonalność pozwalającą na wykorzystanie danych pacjenta celem efektywniejszego przypisania produktów leczniczych, między innymi przez wykrycie przeciwwskazań, interakcji z innymi lekami oraz nadmiaru przyjmowanych dawek, przy uwzględnieniu zastrzeżenia, iż samo oprogramowanie nie wpływa bezpośrednio na ciało człowieka.

\section{Ramy prawne rozstrzygnięcia}

Punktem rozważań prawnych stały się w szczególności art. 1 ust. 1 oraz art. 1 ust. 2 lit. a) dyrektywy 93/42, które określają wyposażenie jako wyrób medyczny oraz definiują pojęcie wyrobu medycznego jako „narzędzie, przyrząd, urządzenie, oprogramowanie, materiał, inny artykuł stosowany samodzielnie lub w połączeniu wraz z wszelkim wyposażeniem, w tym oprogramowaniem przeznaczonym przez 
jego wytwórcę do używania specjalnie w celach diagnostycznych lub terapeutycznych i niezbędnym do jego właściwego stosowania, przeznaczone przez wytwórcę w celach diagnozowania, zapobiegania, monitorowania, leczenia, łagodzenia przebiegu choroby $[\ldots] "$ ".

\section{Stanowisko Trybunału Sprawiedliwości Unii Europejskiej}

W omawianym rozstrzygnięciu Trybunał odniósł sie do kwestii, czy oprogramowanie, którego jedna $\mathrm{z}$ funkcjonalności pozwala na wykorzystanie pewnych danych medycznych dotyczących pacjenta umożliwiających jednostce decyzyjnej monitorowanie jego stanu zdrowia czy przepisanie odpowiednich dlań leków, może być w świetle wspomnianych funkcjonalności traktowane jako wyrób medyczny. Istotnym aspektem tego zagadnienia jest to, że z natury rzeczy oprogramowanie nie wpływa bezpośrednio na ciało człowieka.

$\mathrm{Z}$ analizy wspomnianych artykułów dyrektywy 93/42 wynika, że takie oprogramowanie może zostać zaklasyfikowane jako wyrób medyczny po spełnieniu łącznie dwóch przesłanek warunkujących. Odnoszą sięone do celu i sposobu działania. Badając warunek celowościowy, Trybunał wskazał, ze wyrób musi być przeznaczony przez wytwórcę do stosowania u ludzi w szczególności, aby efektywniej i bezpieczniej móc diagnozować, leczyć i monitorować wszelkie nieprawidłowości wynikające $z$ chorób człowieka. Ponadto Trybunał podkreślił, ze aby wyrób mógł być rozpatrywany pozytywnie w świetle wspomnianej przesłanki, musi być nie tylko wykorzystywany w kontekście medycznym, ale też musi być przeznaczone do celów medycznych. W świetle tych ustaleń Trybunał jasno wskazał, że oprogramowanie, które dostarcza lekarzowi zautomatyzowanej wiedzy, wpływa na proces decyzyjny w wypadku przepisywania leków i umożliwia wskazanie ewentualnych przeciwwskazań oraz interakcji z lekami towarzyszącymi, zatem na mocy art. 1 ust. 2 lit. a) dyrektywy 93/42 może być nazywane wyrobem medycznym.

Ale też oprogramowanie stosowane $\mathrm{w}$ środowisku medycznym służy do archiwizacji personaliów, parametrów medycznych itp. Nie może być zatem traktowane jako wyrób medyczny, gdyż brakuje szczególnego medycznego celu, a wyszczególnienie go jest niezbędne, aby móc dane oprogramowanie zaklasyfikować jako wyrób. Trybunał pochylił sie także nad pytaniem sądu odsyłającego, które dotyczyło tego, czy wyrobem medycznym może być oprogramowanie, które a natura rei nie ma wpływu na ciało człowieka, nie wchodzi z nim w interakcję. Należy na nie odpowiedzieć twierdząco, gdyż odjęcie takiego oprogramowania z pojęcia wyrobu medycznego byłoby niejako wykluczeniem z samej dyrektywy 93/42. Zasadniczymi kwestiami w analizowaniu i klasyfikacji danego oprogramowania są przede wszystkim — jak się rzekło — cel medyczny oraz istniejący kontekst medyczny.

Trybunał nawiązał także do dyrektywy 2007/47, w której prawodawca unijny miał objąć pojęciem wyrobu medycznego oprogramowania bez względu na to, 
czy bezpośrednio oddziaływują na ciało ludzkie ${ }^{1}$, co niewątpliwie skutkowałoby pozbawieniem art. 1 ust. 2 lit. a) tej dyrektywy aspektu skuteczności, który uznawany jest za tak zwany effet utile ${ }^{2}$.

Na potwierdzenie poczynionych rozważań Trybunał powołał sie, na wytyczne Komisji MEDDEV 2.1 (Guidelines on the qualification and classification of stand alone software used in healthcare within the regulatory framework of medical devices - MEDDEV 2.1) dotyczące kwalifikacji i klasyfikacji niezależnego oprogramowania wykorzystywanego w medycynie $\mathrm{w}$ ramach prawnych dotyczących wyrobów medycznych, wskazujących jednoznacznie na to, że wyrobami medycznymi będą te oprogramowania, które zostały przez wytwórcę przeznaczone do realizacji jednego z celów ujętych w art. 1 ust. 2 lit. a) dyrektywy 93/42. Wytyczne te jednoznacznie wskazują, ze nie należy traktować jako wyrób medyczny oprogramowania nieingerującego $\mathrm{w}$ dane oraz tworzącego wyłącznie tak zwaną cyfrową bibliotekę, lecz jedynie ograniczającego się do gromadzenia czy archiwizowania danych.

\section{Analiza i ocena stanowiska Trybunału}

Dokonanie kompleksowej oceny stanowiska Trybunału Sprawiedliwości Unii Europejskiej wymaga przede wszystkim zdefiniowania pojęcia wyrobu medycznego. Zgodnie z dyrektywą Rady o wyrobach medycznych będą to wszelkie przyrządy, pomoce stosowane samodzielnie lub w połączeniu, przeznaczone do celów diagnostycznych, zapobiegawczych, leczniczych, które nie osiągają głównego zamierzonego działania w ciele lub na ciele ludzkim. Ponadto mogą stanowić element składowy produktu leczniczego. Do obrotu mogą być wprowadzone tylko te wyroby, które są oznaczone znakiem „CE” potwierdzającym spełnienie wymogów zasadniczych, czemu towarzyszy numer identyfikujący jednostkę notyfikacyjną. Uzupełniając powyższą definicję o wyrok Trybunału Sprawiedliwości Unii Europejskiej o numerze C-329/16, stanowiący przedmiot niniejszej glosy, wyrobem medycznym będzie oprogramowanie, którego przynajmniej jedną z funkcjonalności jest wykorzystywanie danych dotyczących pacjenta w celach okołomedycznych, nawet jeśli bezpośrednio nie wpływa na ciało człowieka — już samo to decyduje o nadaniu statusu wyrobu medycznego. Wyrób medyczny może pełnić funkcję zastępczą konkretnej funkcji ciała, lecz ma ona charakter mniej lub bardziej czasowy ${ }^{3}$.

1 Dyrektywa Rady 93/42/EWG z dnia 14 czerwca 1993 roku dotycząca wyrobów medycznych, Dz.U. L z 1993 r. Nr 169, s. 1, z późn. zm.

2 M. Krekora, Definicje, [w:] M. Krekora, M. S'wierczyński, E. Traple, Prawo farmaceutyczne, Warszawa 2020, s. 31.

${ }^{3}$ M. Drummond, A. Griffin, R. Tarricone, Economic evaluation for devices and drugs Same or different?, „Value in Health” 12, 2009, nr 4, s. 402. 
Niewątpliwie uzyskanie statusu wyrobu medycznego niesie z sobą korzyści, z których chcieliby skorzystać zarówno producenci, jak i potencjalni konsumenci. Ustawodawca, tworząc procedury klasyfikujące dany produkt jako wyrób medyczny, kierował się między innymi zapewnieniem bezpieczeństwa i zdrowia pacjentów.

Oprogramowanie medyczne, uzyskawszy rangę wyrobu medycznego, nie tylko zyskuje możliwość dotarcia do szerszego grona konsumenckiego, lecz także możliwość rozwoju systemu zdalnej pomocy medycznej, który w obecnych czasach tworzy podstawową formę kontaktu z lekarzem. W przytoczonym stanie faktycznym oprogramowanie $\mathrm{w}$ istocie rzeczy jest produktem zapewniającym zautomatyzowaną analizę wykrywającą ewentualne przeciwwskazania oraz proponującą potencjalny sposób dawkowania leków z uwzględnieniem dawek maksymalnych. Jest zatem elementem terapii wspomagającym lekarza w monitorowaniu stanu zdrowia pacjenta, nieodłącznie towarzysząc mu przez cały proces rekonwalescencji. Oprogramowanie to uwzględnia w analizach także sposoby łagodzenia przebiegu choroby oraz archiwizuje wszelkie dane na temat kuracjusza.

Na jedną z korzyści, jakie wiążą się z zaklasyfikowaniem oprogramowania do wyrobów medycznych, składa się zwiększenie bezpieczeństwa pacjentów, gdyż zgodnie z art. 46 ustawy z dnia 5 grudnia 1996 roku o zawodach lekarza i lekarza dentysty lekarz nie może sprzedawać wyrobów medycznych ${ }^{4}$. Takie założenie prawne zabezpiecza pacjentów przed ewentualnym ryzykiem nabycia substancji - czy też w analizowanym przypadku oprogramowania - którego stosowanie powinno odbywać się wyłącznie pod szczególną opieką lekarza. Należy mieć na względzie, że tego typu materia nie stanowi dobra powszechnego, którego zażywanie, stosowanie będzie niosło zawsze pozytywne efekty. Wobec poczynionych rozważań trudno nie zgodzić się ze stanowiskiem Trybunału, który jasno wskazuje, że oprogramowanie niewątpliwie realizuje cel wspierania procesu leczenia oraz plasuje się w szeroko pojmowanym kontekście medycznym.

Klasyfikacja jako wyrób medyczny tak ważnego elementu procesu rekonwalescencji, jakim jest omawiane oprogramowanie, służy przede wszystkim zapewnieniu pacjentowi bezpieczeństwa w wyniku większej kontroli nad produktem. Wyroby medyczne muszą bowiem być poddane tak zwanej ocenie klinicznej, zgodnie z którą, gdy dysponent wyrobem będzie posługiwał się specyfikiem zgodnie z instrukcją (przygotowaną na podstawie konkretnych badań), nie dozna on zagrożenia zdrowia czy życia. Proces takiej ewaluacji produktu jest szczególnie ważny i dokonywany przed odrębną, niezależną jednostkę

${ }^{4}$ Ustawa z dnia 5 grudnia 1996 roku o zawodach lekarza i lekarza dentysty, tekst jedn. Dz.U. z 2020 r. poz. 514 z późn. zm.

${ }^{5}$ K. Sojka, Wyroby medyczne z punktu widzenia Apteki Szpitalnej stosowane w Oddziale intensywnej terapii, praca dyplomowa napisana w Collegium Medicum Uniwersytetu Jagiellońskiego, Kraków 2020. 
Trybunał Sprawiedliwości Unii Europejskiej podkreśla w swoim orzeczeniu wagę realizowania szczególnego medycznego celu — jest to niewątpliwie jedna z przesłanek, bez której oprogramowanie nie mogłoby zostać zaliczone do wyrobu medycznego. Odwołując się do powszechnie rozumianej interpretacji pojęcia celu, można stwierdzić, że w tym kontekście będzie to dążenie do czegoś lub służenie czemuś. Do realizacji tej przesłanki przysłuży się między innymi zalecenie Komisji 2013/172/UE z 5 kwietnia 2013 roku w sprawie wspólnych ram dotyczących systemu niepowtarzalnych kodów identyfikujących wyroby medyczne, w którym wprowadzono wspólny system identyfikacyjny dla wyrobów medyczny określany skrótem UDI ${ }^{6}$. System ten wprowadzono po to, aby móc łatwo zidentyfikować produkt stosowany lub wycofany przy użyciu kodu stosowanego w odniesieniu do wszystkich specyfików w bazie UE. Baza ta ma uniemożliwić popełnianie błędów medycznych powszechnie występujących w przypadkach użycia niewłaściwego wyrobu. UDI zwiększa bezpieczeństwo pacjentów, a zarazem wzmacnia kondycję gospodarki przez kontrolę dystrybucji wyrobów medycznych. System UDI to jeden z przykładów wspierania procesu leczniczego, przejawiającego się we wsparciu wyboru odpowiednich do schorzenia wyrobów medycznych, co zapobiega błędom o znaczących konsekwencjach dla kuracjuszy. Wydaje się zatem, że UDI powinno mieć też zastosowanie w klasyfikacji oprogramowań jako wyrobów medycznych.

Rozpatrując słuszność zaliczenia przez Trybunał Sprawiedliwości Unii Europejskiej oprogramowania do wyrobów medycznych, nie można zapomnieć o nowym kontekście związanym z panującą od roku 2020 pandemią SARS-CoV-2 i reakcją branży medycznej na zmodyfikowane potrzeby społeczeństwa. Należy pamiętać, że TSUE wypowiedział się w sprawie C-320/16 w roku 2017. Realia czasów pandemicznych sprawiają, że należy podzielić stanowisko TSUE, który włączył oprogramowanie do ram wyrobów medycznych. Parlament Europejski 24 kwietnia 2020 roku włączył do systemu prawnego zmianę rozporządzenia Parlamentu Europejskiego i Rady (UE) 2017/745 z dnia 5 kwietnia 2017 roku w sprawie wyrobów medycznych i zmiany dyrektywy 2001/83/WE ${ }^{7}$. Jednymi z punktów, które zostały uwzględnione, są wyciągnięcie niejako przed ustawodawczy nawias kwestii związanej z zachowaniem przez producentów wyrobów medycznych jakości produktów oraz ustanowienie systemu zarządzania zapobiegania incydentom związanym z takimi wyrobami. Producenci powinni także ustanowić system korygujący błędy (pkt 32). Interesujący jest również pkt 72,

6 Zalecenie Komisji 2013/172/UE z 5 kwietnia 2013 roku w sprawie wspólnych ram dotyczących systemu niepowtarzalnych kodów identyfikujących wyroby medyczne, Dz.U. L 99 z 9 kwietnia $2013 \mathrm{r}$.

7 Rozporządzenie Parlamentu Europejskiego i Rady (UE) 2017/745 z dnia 5 kwietnia 2017 roku w sprawie wyrobów medycznych, zmiany dyrektywy 2001/83/WE, rozporządzenia (WE) nr 178/2002 i rozporządzenia (WE) nr 1223/2009 oraz uchylenia dyrektyw Rady 90/385/EWG i 93/42/EWG, Dz.U. L. z 2017 r. nr 117, s. 1, z późn. zm. 
który zobowiązuje producenta wyrobu medycznego do odgrywania czynnej roli w gromadzeniu materiału dotyczącego produktu po jego wprowadzeniu. Między innymi odnosi się to do tworzenia dokumentacji uaktualniającej proces stosowania leku oraz współpracy na rynku. Zobowiązuje on producentów do tworzenia kompleksowego systemu nadzorczego, z którego będzie można pozyskiwać informacje, wyciągać wnioski z podjętych działań oraz na nim będzie się można opierać, tworząc nowe produkty w przyszłości. Jest to zagadnienie, które należy ocenić pozytywnie, gdyż w świetle wyroku TSUE nr C329/16 oprogramowanie jako wyrób medyczny zostało objęte wymienioną dyrektywą, co za tym idzie - zyskało niejako podwójną ochronę prawną. Również z twórcy takich oprogramowań — będących wyrobami medycznymi — zostają objęci taką ochroną. W obecnej sytuacji epidemiologicznej bez wątpienia należy uznać, że wszelkie działania Unii w kierunku zapewnienia bezpieczeństwa, poprawy jakości wyrobów oraz zabezpieczania przez incydentami będą postrzegane pozytywnie.

W toku rozważań nie można pominąć tego, że Trybunał Sprawiedliwości Unii Europejskiej nie zaliczył każdego oprogramowania medycznego jako wyrobu medycznego. Software, który zakłada sam w sobie jedynie gromadzenie danych na temat pacjentów, nie może być uznany za wyrób medyczny. Samo zbieraniae pewnych informacji nie może decydować o statusie omawianego wyrobu, gdyż nie spełnia to medycznego celu samego w sobie. Wpisuje się to jedynie w kontekst medyczny związany z usprawnianiem działania oraz porządkowaniem, sekwencją danych. Jest to niewątpliwie istotny element w całym procesie funkcjonowania systemu medycznego, natomiast nie może posłużyć jako uzasadnienie przyznania produktowi rangi wyrobu medycznego. Istnieją w branży medycznej systemy czy oprogramowania umożliwiające sortowanie danych lub ich wyszukiwanie. Trudno w takiej sytuacji nie zgodzić się ze stanowiskiem Trybunału, że taki software nie może być traktowany jako wyrób medyczny, zwłaszcza w porównaniu z systemem, który w sposób kompleksowy odnosi się do stanu zdrowia jednostki, włączając w to kwestie związane z dawkowaniem leków i ewentualnym oddziaływaniem między przyjmowanymi specyfikami. Należy zatem zdecydowanie zaaprobować omawiany wyrok, gdyż Trybunał w orzeczeniu kierował się przede wszystkim dobrem jednostki, potencjalnego pacjenta, który z racji swojego położenia, ograniczonej wiedzy medycznej, znajduje się na słabszej pozycji, uwzględniając wszelkie elementy charakteryzujące zarówno wyrób medyczny, jak i możliwości jego użytkownika, od którego przede wszystkim zależy powodzenie w zastosowaniu specyfiku. Trybunał miał na względzie także dobro całego systemu zdrowia, przychylając się do stanowiska skarżących, rozważając tę kwestię w odniesieniu do bezpieczeństwa i kondycji gospodarki.

Należy mieć na uwadze specyfikę wyrobu medycznego, wedle której skuteczność oddziaływania na ciało człowieka zależy przede wszystkim od umiejętności tak zwanego operatora; krzywa uczenia się wyraźnie obrazuje wpływ doświadczenia 
oraz umiejętności na powodzenie we wprowadzeniu wyrobu. Prawidłowe stosowanie danego oprogramowania w kuracji wymaga przede wszystkim zdobycia przez lekarza nadzorującego specjalnej wiedzy, nie wystarczą tu umiejętności manualne w obsłudze programu, konieczna okazuje się wiedza, którą dysponuje wyłącznie specjalista z danej dziedziny medycyny.

Ustawodawca, nie wymagając, aby molekuły danej substancji zawartej w wyrobie medycznym wpływały na poszczególne składniki komórek ludzkiego ciała, kierował się w głównej mierze tym, że zupełnie wystarczające jest wykazanie, iż molekuły wspomnianej rozpatrywanej substancji współdziałały w jakikolwiek, nawet minimalny, sposób z ciałem pacjenta ${ }^{8}$. W tym świetle korzystanie z oprogramowania medycznego wpisuje się w ciągły proces leczniczy, wymagający posiadania specjalistycznej wiedzy, umiejętności oraz zdolności zastosowania ich w praktyce zarówno w odniesieniu do ciała człowieka, jak i systemu oprogramowania?

Ponadto warte uwagi wydaje się to, że aspekt wpływu bezpośredniego na ciało człowieka nie jest elementem warunkującym klasyfikowanie produktu jako wyrobu medycznego, dzięki czemu może być tym pojęciem objęte oprogramowanie medyczne. Trybunał niewątpliwie, rozpatrując kwestię pod kątem funkcjonalności, uwzględnił oczywisty fakt, że każdy produkt ma swoje granice i sposoby oddziaływania — tu oprogramowanie medyczne z natury nie ma możliwości modyfikowania ciała pacjenta, natomiast za jego pomoca lekarz podejmuje decyzje o sposobie leczenia, dawkowaniu leków, co summa summarum wykazuje wpływ produktu na zdrowie pacjenta. Rozpatrując tę sytuację, należy odwołać się do tak zwanego adekwatnego związku przyczynowo-skutkowego, który zakłada ustalenie, czy fakt B by się pojawił, gdyby nie nastąpił fakt A. Zakładając, że oprogramowanie medyczne będzie faktem A, a wpływ na organizm człowieka faktem B, można dojść do wniosku, że jest on conditio sine qua non przy podejmowaniu decyzji przez lekarza rozpatrującego stan zdrowia jednostki. Trybunał wyraźnie zakomunikował, że bezpośrednie oddziaływanie na ciało nie jest istotne $\mathrm{z}$ punktu klasyfikacji danego produktu jako wyrób medyczny oraz kwestią, nad którą w tym casusie należy się pochylić, będą szeroko rozumiany cel medyczny oraz kontekst medyczny.

Warte rozważenia wydaje się stanowisko przedstawione przez J. Matarewicz, traktujące o tym, że instalacja gazów medycznych stanowi zarówno w świetle prawa krajowego, jak i oczywiście unijnego właśnie wyrób medyczny ${ }^{10}$. Jest to przykład ściśle korelujący z przypadkiem, z jakim zmierzył się Trybunał w spra-

8 Wyrok Trybunału Sprawiedliwości z dnia 6 września 2012 roku, C-308/11, Chemische Fabrik Kreussler \& Co. GMBH vs Sunstar Deutschland GMBH, ZOTSiS 2012, nr 9, poz. I-548.

9 M. Koperny et al., Wytyczne oceny technologii medycznych. Wyroby medyczne (medical devices). Przeglad aktualnego stanu wiedzy i rozwiazań, Agencja Oceny Technologii Medycznych i Taryfikacji, Wydział Świadczeń Opieki Zdrowotnej 2019.

10 J. Matarewicz, Dostawa instalacji gazów medycznych, [w:] Przestęstwa karuzelowe i inne oszustwa w VAT, red. I. Ożóg, Warszawa 2017, s. 313. 
wie C-329/16, gdyż instalacja gazów medycznych w rzeczy samej nie oddziałuje na ciało ludzkie, ale prawo ze względu na budowę, jak też sposób certyfikacji oraz skomplikowane procedury związane z instalacją nakazuje traktować ją właśnie jako wyrób medyczny. Realizacja zamówienia kontrahenta na usługi budowlano-montażowe związane z instalacją gazów medycznych będzie zatem zakupem wyrobu medycznego. Nie może stać się tak, że specjalistycznie przygotowane rurociągi będą traktowane tak samo jak powszechna instalacja gazowa, która wymaga całkiem innego przygotowania, zabezpieczenia oraz obsługi.

Uzyskanie statusu wyrobu medycznego skutkuje między innymi określeniem ściślejszej formy kontroli, obsługi, zmianą sytuacji podatkowej, której w Polsce odpowiada stawka podatku VAT $8 \%$. Ponadto zmiana w ustawodawstwie we wspomnianym zakresie $\mathrm{z}$ jest pewnym elementem systematyzacji $\mathrm{w}$ doktrynie, wedle której oddziaływanie na ciało ludzkie nie jest elementem conditio sine qua non traktowania produktu jako wyrób medyczny. Wyrok Trybunału Sprawiedliwości Unii Europejskiej w sprawie C-329/16 wprowadza w przytoczonym stanie faktycznym element harmonizujący w zakresie wymiany handlowej na rynku wewnętrznym, co niewątpliwie należy oceniać dodatnio. Procedura legalizacji oprogramowania na rynku medycznym stała się bardziej oszczędna pod względem ekonomicznym oraz temporalnym. Nakładanie na producentów dodatkowych wymogów, które dotychczas obowiązywały w prawie francuskim, stanowiło przeszkodę $\mathrm{w}$ swobodnym przepływie towarów, ponadto generowało zbędne procedury formalne związane między innymi z dodatkową certyfikacją, pomijając podstawowe, jak się okazuje wystarczające, oznakowanie „CE”. Oznaczenie to bowiem spełnia wymogi związane z zapewnieniem bezpieczeństwa i zdrowia przy stosowaniu produktu. Oprogramowanie, które może być uznane za wyrób medyczny, musi i tak realizować wiele kwestii zarówno odnoszących się do samego produktu w ujęciu merytorycznym, jak i spełniających wszelkie przesłanki związane z praktycznym wykorzystaniem.

Zestawiając scharakteryzowany stan faktyczny z art. 168 ust. 1 Traktatu o funkcjonowaniu Unii Europejskiej, należy ocenić wyrok Trybunału Sprawiedliwości Unii Europejskiej jako w pełni korespondujący ze wskazanymi przepisami nakazującymi w obrębie Unii realizowanie na wysokim poziomie ochronę zdrowia życia ludzkiego oraz kierowanie się w swoich działaniach poprawą zdrowia publicznego ${ }^{11}$. Realizacja wspomnianej normy ma się odbyć za pomocą oceny produktów leczniczych stosowanych u ludzi, promowanie wiedzy dotyczącej ogólnodostępnych leków, wypracowanie skutecznych procedur pozwalających na szybki dostęp do leków mających w sposób bezpieczny i humanitarny nieść pomoc ${ }^{12}$.

11 Traktat ustanawiający Europejską Wspólnotę Gospodarczą, Dz. U. z 2004 r. Nr 90, poz. 864/2 z późn. zm.

12 M. Malczewska, Art. 168, [w:] Traktat o funkcjonowaniu Unii Europejskiej. Komentarz, t. 2. Art. 90-222, red. K. Kowalik-Bańczyk, M. Szwarc-Kuczer, A. Wróbel, Warszawa 2012, s.1041. 
Oznakowanie oprogramowania medycznego statusem wyrobu medycznego jest przejawem zainteresowania doktryny aspektem zdrowia jednostki, unowocześniania aparatu przez rozszerzanie zespołu pomocy medycznych, które nieodłącznie składają się na doskonale znany jednostce system. Spoglądając na problem pod kątem ekonomicznym, należy pamiętać, że Trybunał nie kierował się wolą zredukowania wydatków (co między innymi potwierdza A. Wesołowska, podkreślając, że koszt wyrobów medycznych jest ponoszony często przez bezpośredniego konsumenta końcowego, ze względu na jego zastosowanie, które jest skierowane do profesjonalistów z sektora zdrowotnego ${ }^{13}$ ), co niewątpliwie przesądza o wadze problemu oraz ujmowaniem w przyszłości prawa medycznego w ramach pozostałych nauk prawnych. Poszerzanie kręgu wyrobów medycznych mnoży dodatkowe wydatki, co rodzi problem, z którym Unia oraz poszczególne państwa muszą się zmierzyć. Niemniej jednak nadaje to pewien kształt ponadnarodowego systemu medycznego stanowiącego urzeczywistnienie przyjętych traktatów. Badania kliniczne czy wymogi uzyskania przez wytwórcę pozwolenia wprowadzenia leku na rynek stanowią tylko część składową wysokiej jakości usług świadczonych przez unijny system zdrowia, w które niewątpliwie wpisuje się każde oprogramowanie klasyfikujące się do miana wyrobu medycznego, realizujące szeroko pojęte normy polityki farmaceutycznej ${ }^{14}$.

Omawiane w niniejszej glosie orzeczenie jest wyrazem ustawodawczego pochylenia się nad istotnymi z punktu widzenia praktyki dyrektywami nowego podejścia. Zawarte są $\mathrm{w}$ nich wymogi związane $\mathrm{z}$ bezpieczeństwem, określają bowiem, jakie normy powinien spełniać wyrób, a także, co ważne, nie uzależniają wprowadzenia produktu na rynek od procesu autoryzacji urzędowej. Całą odpowiedzialnością $\mathrm{w}$ tej kwestii obarczony jest producent, który na podstawie dyrektywy oraz wiedzy z zakresu wprowadzanego przez siebie produktu ma obowiązek przeprowadzić kompleksową implementację obowiązujących zasad ${ }^{15}$. Wydawać się może, że jeden wyrok Trybunału nie okaże się istotny dla prawodawstwa, biorąc pod uwagę problemy, z jakimi spotykają się kraje unijne, natomiast w niniejszej rozprawie przyjmuje się, że stanowisko Trybunału świadczy o tym, iż judykatura wskazuje na istotę budowania i udoskonalania mechanizmu funkcjonowania struktur medycznych. Odzwierciedla to pewnie dążenia jurysdykcyjne wykazujące wyraźną spójność między głosem potrzeb ludzkich a intencjami tych, którzy zwykli na te myśli odpowiadać. Komentowane orzeczenie zwróciło uwagę na problem klasyfikacji wyrobu medycznego, jego wpływu na ciało człowieka oraz fakt, że nie każde oprogramowanie medyczne będzie stanowiło wyrób medyczny na tle rozpatrywanych przepisów. Trybunał, pochylając się nad wymie-

13 A. Wesołowska, Stosowanie obniżonych stawek podatku VAT dla dostawy produktów farmaceutycznych, Glosa do wyroku Trybunału Sprawiedliwości z dnia 4 czerwca 2015 r., C-678/13, LEX 2015.

14 Ibidem.

15 Ibidem. 
nionymi kwestiami, postawił krok w kierunku doprecyzowania, uporządkowania pojęć będących dla prawa unijnego niezbędnym składnikiem ujednolicającym oraz hierarchizującym pewne wartości.

Trybunał Sprawiedliwości Unii Europejskiej wskazał, że oprogramowanie medyczne może stanowić wyrób medyczny, oraz określił, że taki produkt nie musi mieć bezpośredniego wpływu na ciało człowieka. Ponadto orzekł, że aby oprogramowanie wyczerpywało znamiona wyrobu medycznego, musi dysponować większymi możliwościami i narzędziami niż te jedynie gromadzące dane.

Konkludując, należy uwypuklić tezę Trybunału Sprawiedliwości Unii Europejskiej, który w wydanym orzeczeniu pochylił się nad stanowiskiem strony skarżącej, jednocześnie kierując się przede wszystkim bezpieczeństwem i dobrem jednostek, przemówił na ich korzyść. Wyrok Trybunału Sprawiedliwości Unii Europejskiej w sprawie C-329/16 wypełnił pewną lukę prawną związaną z podzielonymi stanowiskami zarówno na temat systematyzacji pojęcia wyrobu medycznego, jak i samego wpływu wspomnianego produktu na ciało ludzkie. Wniesione zmiany wprowadziły pożądany ład w przepisach związanych z klasyfikacją oprogramowań i rozwiały wątpliwości co do wpływu wspomnianego software'u na organizm człowieka.

\section{Bibliografia}

Drummond M., Griffin A., Tarricone R., Economic evaluation for devices and drugs - Same or different?, „Value in Health” 12, 2009, nr 4.

Dyrektywa Rady 93/42/EWG z dnia 14 czerwca 1993 r. dotycząca wyrobów medycznych, Dz.U. L z 1993 r. nr 169, s. 1, z późn. zm.

Koperny M., Konieczna M., Głowik P., Siwiec J., Dziurda D., Sejbuk K., Wysoczański W., Wytyczne oceny technologii medycznych. Wyroby medyczne (medical devices). Przeglad aktualnego stanu wiedzy i rozwiązań, Agencja Oceny Technologii Medycznych i Taryfikacji, Wydział Świadczeń Opieki Zdrowotnej 2019.

Krekora M., Definicje, [w:] M. Krekora, M. Świerczyński, E. Traple, Prawo farmaceutyczne, Warszawa 2020.

Malczewska M., Art. 168, [w:] Traktat o funkcjonowaniu Unii Europejskiej. Komentarz, t. 2. Art. 90-222, red. K. Kowalik-Bańczyk, M. Szwarc-Kuczer, A. Wróbel, Warszawa 2012.

Matarewicz J., Dostawa instalacji gazów medycznych, [w:] Przestępstwa karuzelowe i inne oszustwa w VAT, red. I. Ożóg, Warszawa 2017.

Rozporządzenie Parlamentu Europejskiego i Rady (UE) 2017/745 z dnia 5 kwietnia 2017 roku w sprawie wyrobów medycznych, zmiany dyrektywy 2001/83/WE, rozporządzenia (WE) nr 178/2002 i rozporządzenia (WE) nr 1223/2009 oraz uchylenia dyrektyw Rady 90/385/EWG i 93/42/EWG, Dz.U. L. z 2017 r. nr 117, s. 1, z późn. zm.

Sojka K., Wyroby medyczne z punktu widzenia Apteki Szpitalnej stosowane w Oddziale intensywnej terapii, praca dyplomowa napisana w Collegium Medicum Uniwersytetu Jagiellońskiego, Kraków 2020.

Traktat ustanawiający Europejską Wspólnotę Gospodarczą, Dz.U. z 2004 r. Nr 90, poz. 864/2 z późn. zm.

Ustawa z dnia 5 grudnia 1996 roku o zawodach lekarza i lekarza dentysty, Dz.U. z 2020 r. poz. 514 z późn. zm. 
Wesołowska A., Stosowanie obniżonych stawek podatku VAT dla dostawy produktów farmaceutycznych, Glosa do wyroku Trybunału Sprawiedliwości z dnia 4 czerwca 2015 r., C-678/13, LEX 2015.

Wyrok Trybunału Sprawiedliwości z 6 września 2012 r., C-308/11, Chemische Fabrik Kreussler \& Co. GMBH vs Sunstar Deutschland GMBH, ZOTSiS 2012, nr 9, poz. I-548.

Zalecenie Komisji 2013/172/UE z 5 kwietnia 2013 roku w sprawie wspólnych ram dotyczących systemu niepowtarzalnych kodów identyfikujących wyroby medyczne, Dz.U. L 99 z 9 kwietnia $2013 \mathrm{r}$.

Studenckie Prace Prawnicze, Administratywistyczne i Ekonomiczne 37, 2021 (C) for this edition by CNS 
